\title{
It all began with an invitation - from China.
}

\author{
Manfred F. Romich \\ dr.romich@ize-aachen.de
}

\begin{abstract}
Copyright $(\mathcal{C} 2020$ Manfred F. Romich. This text may be archived and redistributed both in electronic form and in hard copy, provided that the author and journal are properly cited and no fee is charged, in accordance with our Creative Commons Licence.
\end{abstract}

Abstract: An account of how the author and Geoff travelled together to China several times. Forty years of friendship and common interests are fondly remembered.

Keywords: Geoff Davis, China, travelling companion

Within the framework of a project-based seminar I was running at the time I had sought official permission to undertake a research trip to China. This was back in 1978. The longed-for invitation from Peking came unexpectedly soon - and was then granted for two trips. Since our Department didn't really know how to proceed, I was sent to see the Vice-Chancellor. The Vice-Chancellor, by contrast, had a very clear idea about how to handle things. "Okay", he said, "you can go. But the first trip should be reserved for members of staff. The second one can be open to students." A group of professors from various faculties was quickly assembled - but there were still some places left. Then somebody piped up: "Why don't we ask that chap Davis from the English Department. He loves travelling." No sooner said than done. Geoff was invited round to the ViceChancellor's office to introduce himself. The welcome he got was rather special. Somebody present remarked: "Ah, so you're the one who failed my wife in that language proficiency test." Geoff kept his cool: "Sorry 'bout that." At the time he was also in a clinch with the University over his employment contract but that didn't seem to be a problem: "Ok, it can't count as an official trip but you can still go." Oh, well, he would manage to scrape the money for China together somehow or other.

And so off we set in November 1978. Geoff and I had very quickly realized that we had a lot in common. We both loved flying, we both loved getting to know new places, we were both very curious - and neither of us had much money. Probably because we were always spending it on travel. We flew with Lufthansa via the North Pole to Tokyo, where we had a short stay, overnighting in a luxury hotel. We did a tour of the city and were 


\section{Coolabah, Nr 28, 2020, ISSN 1988-5946, Observatori: Centre d'Estudis Australians $i$ \\ Transnacionals / Observatory: Australian and Transnational Studies Centre, Universitat de Barcelona}

astonished to see the prices in Japanese restaurants. And then the onward journey immediately continued, this time with PIA ("Please Inform Allah!" - that was yet another thing in common: we both enjoyed thinking up alternative names to fit the airline codes. And apart from that, we both "knew" a whole lot about flying and loved to show off our "knowledge" (without being asked). When had a plane of the same type crashed? What technical faults did which individual types of plane have? Who had the nicest stewardesses? And so on and so forth. We had a whale of a time just talking planes. When there was something I didn't know, he could fill me in or vice versa. All this didn't necessarily help to keep our fellow-passengers calm. After all, who wants to hear about the design flaws of the airplane they're actually sitting in.

The Boeing 707 from Tokyo to Peking wasn't exactly overbooked and so we managed to persuade the flight attendant to let us check out the cockpit. It was simply great to stand behind the pilot and look through the cockpit window into the great wide open. Where exactly were we now? We had flown round Korea (the airspace was blocked) and after glancing out of the window the pilot informed us: "We're looking for Shanghai." As Geoffrey and I were leaving the cockpit, the flight engineer (yes, they still had them then) turned to us and asked: "Would you like a drink?" He was handing us a half-empty bottle of whisky." "No, thanks" we said and returned to our seats. Geoffrey fastened his seat belt just a little bit tighter than usual. And the actual landing in Peking was in fact pretty bumpy and scary. Visibility was poor and after feeling the plane almost scrape along the grass as it did a steep turn, we were quite relieved when we finally landed safe and sound on the tarmac. We exited the plane on the airfield. Someone was pointing in the general direction of the arrivals building, saying: "You can't miss it." A gigantic portrait of Mao was hanging over the entrance. We had arrived. To be welcomed by a representative of the German Embassy. Geoff was okay with that - but the British representative might have come along too, might he not...?

We didn't need to bother about luggage and suchlike. How should I put it? - our reception was definitely VIP-style. Two interpreters were assigned to us. They were to accompany us throughout our stay. They took us from the airport to the hotel. On the way there we were all fairly quiet. We were suddenly immersed in a different world: fields on which peasants were working under red flags; people in uniformly blueish-grey work clothes; no cars - just a few hand tractors instead; no end of bicycles and donkey-carts. So this was the realm of socialism.

In the Friendship Hotel we all met up again in the bar. A colleague bought a round of drinks. Happy to have survived the flight, he observed: "The pilot must have been a good airman in the Pakistan Army." Our rooms in the Friendship Hotel were enormous suites, complete with desk and telephone, with words of the Chairman himself on the dial. Geoff took a photograph - one of the first of the trip. Our programme began the following day: sightseeing, lectures, chats. Interrupted only by opulent meals, with ten to twelve courses consisting of the finest dishes. Geoffrey liked to use chopsticks - another thing we had in common. 
In those days there were limitations on the number of films you could have with you (this was till the digital age) so we had to make do with the few we had. You could buy additional films but they were very expensive. However, Geoffrey had to buy some...

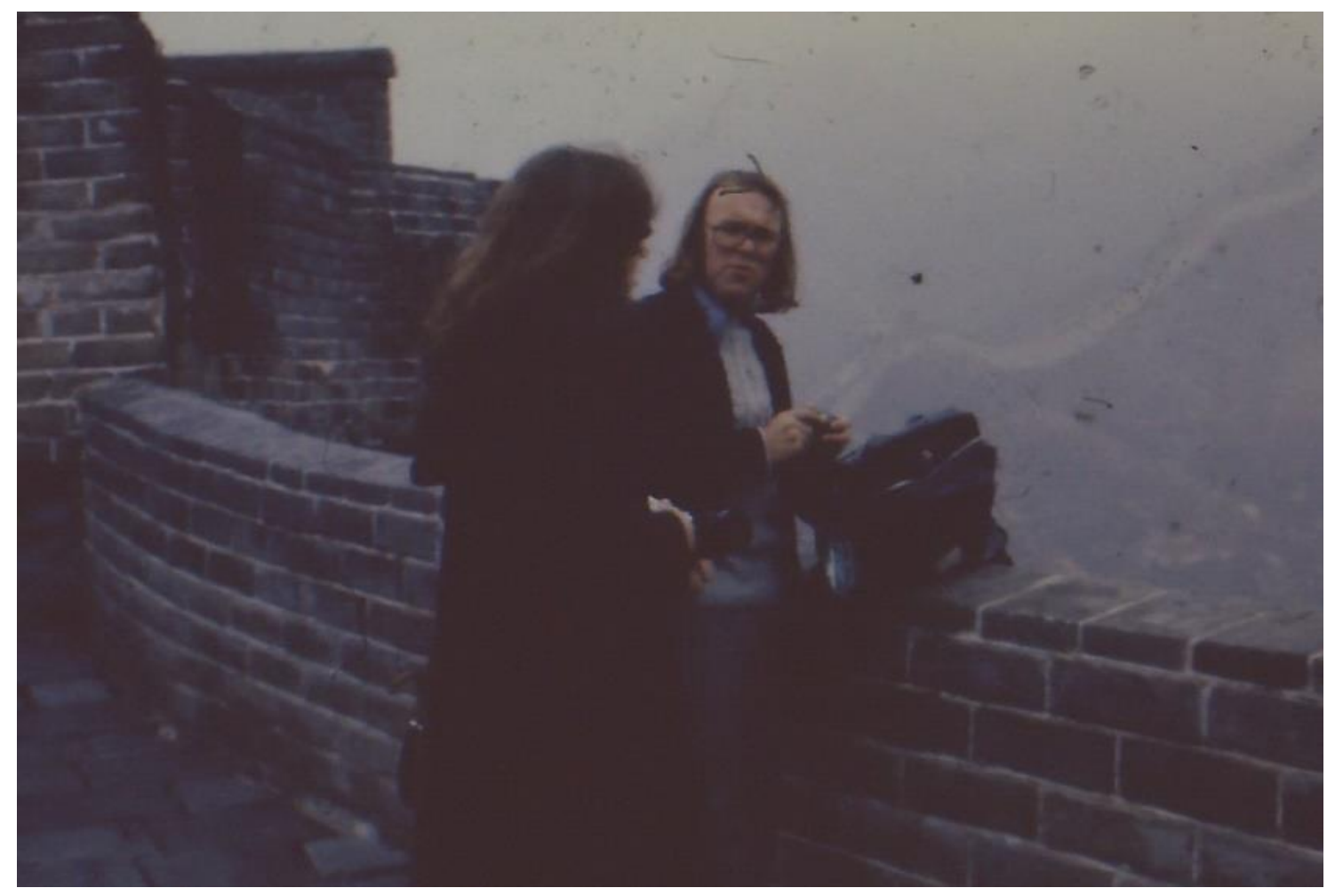

I have fond memories of the long overnight train journeys. We had berths in a sleeper. These journeys had three distinguishing features: firstly, you could hardly sleep; secondly, you spent a lot of time in the dining-car; and thirdly, you prevented the interpreters from getting any sleep. Geoffrey and I enjoyed returning to the dining-car after dinner. The only people there by then were the train crew. Astonished but interested faces looked at us: What are the long noses doing here?

I usually ordered a couple of beers for us: "Beijing Pijiu" or "Qingdao Pijiu". My order in Chinese usually caught the attention of the locals which was further sparked by Geoff's diligent writing of Chinese characters in his diary - with which the Chinese always and eagerly offered to help. And so, we ended up in lively discussions with the locals, had our drinks and even received some snacks for free. What a great way to travel! When we were not in the dining car we were standing or sitting in the corridor, trying to engage our interpreters in conversation. "Where is China heading?" we would ask. "What about Hua Guofeng?" "What about the Gang of Four?" We had seen wall newspapers. "How important are they these days?" we wanted to know. Etcetera, etcetera. On one occasion one of the interpreters took me on one side and asked me: "Your colleague - he's not German, is he? He's somehow different." "Well, he's British, isn't he?" How on earth had she spotted that?

In Guangzhou we bumped into a painter who was producing huge portraits of the new Chairman Hua Guofeng. Geoff was visibly impressed by the man's artistry - that too had 
to be photographed. Then we left China. Our train went as far as the border bridge and then we carried our cases across the bridge. We had arrived in Hong Kong. Immigration formalities. For the Germans, a short residence permit. For the Brit, a very long residence permit. A quick grin: "Sorry 'bout that." In China we had really enjoyed the Chinese food. The last meal we had had there had been the snakes in Guangzhou. But what were things going to be like now we were in Hong Kong? Nothing here was as thoroughly organised as in China. Nevertheless, the British dimension made a lot of things easier than in China. We were staying in the Furama Intercontinental. A first-class hotel, no question. Very Western and - most importantly - it boasted a café: The Café Vienna. British or not, Geoff made his way straight to that café. No more green tea. Proper coffee again and apple strudel with cream to go with it. After all, he was a gourmet, wasn't he?

And for Hong Kong there were decent travel guides again, so Geoff could read up what was going on, where to go and what you could do there. Sometimes the "must-do's" didn't match the means available for our budget. What really was a must, though - there was no way round it - was enjoying a whisky in the foyer of the Peninsula Hotel. And there I must admit I didn't say "No" either - despite the prices, which were of course astronomical compared with China. When the time came for our return flight, a surprise was awaiting us. The Lufthansa DC-10 that was to take us to Frankfurt was grounded. Following a crash, this type of plane was not allowed to fly at all. So our booking was switched to Pan Am Flight No. 1, west-bound from Los Angeles to New York - around the world, stopping among other places in Hong Kong and Frankfurt. Only shortly after take-off, Geoff and I were in full agreement. We had the oldest and unfriendliest stewardesses we had ever seen. How could the Yanks allow such people to fly? What a good thing times have changed since then. Today such remarks would meet with harsh criticism.

And then here we were again, back in Germany. What the heck?! Life goes on - there's always another trip. I can't remember whether I had to persuade Geoff to join us again the following year - 1979. Looking back, I have the feeling I didn't even need to ask. And so we set off for China again, this time with students from the project-based seminar. The trip was at least as interesting as the first China trip. What was different was that this time our interpreters' sense of humour was somewhat underdeveloped and they didn't want to play Mahjong on the overnight trains or have long discussions with us. This time the powers that be had picked some really "tough cookies" - to make sure this crowd of Western students were kept in check. But there was another surprise on this trip: we were on television!

In Peking we were invited by the President of the Pan-Chinese Women's Federation and Vice-President of the People's Congress, Ms Kang Keqing, to attend a reception and take part in a discussion in the Great Hall of the People. This was highly theatrical, statesponsored stuff. We entered the Great Hall of the People, the seat of Parliament, on Tiananmen, the Square of Heavenly Peace. Television cameras in front, next to and behind us. Lots of ceremonial activity, a lecture, a discussion, followed by posing for the group photo, which had of course been rehearsed before the actual reception took place. It was all enormously and unbelievably impressive. In the evening we sat in front of the 
TV set, waiting for the news of the official reception of the group from Germany to be screened. It was all highly cinematic. In one shot, Geoff could be seen from behind - not at all good for him. He realised for the first time that his hair wasn't developing evenly in all places. On the following day the official photo appeared in the newspaper - taken from the front this time. That looked quite ok.

Geoff and I were among the few members of the party to enthuse about the Peking operas that lasted for hours and hours but also about romantic musical compositions such as "The Butterfly Lovers", about which our interpreters told us such beautiful stories. Of course we would have loved to see the revolutionary operas but they were already a thing of the past. As we were also told when we tried to buy a "Mao Bible": "The time is over." And then it turned out that they did still have a copy - under the counter. Our enthusiasm for the Chinese theatrical performances was so great that we bought a stage sword each. They were really big and looked extremely martial. But what was the consequence? Chaos at the airport check-in. "No, that's not permitted!" "No!" we said, "we have to take them with us!" Geoff tried using a bit of British humour but that didn't go down too well with the Chinese. Nevertheless, the swords did find their way to Germany in the shape of "accompanying baggage". As did a set of four targets (bearing the heads of the Gang of Four) and a pistol with a rubber arrow. All items that were of great interest to the airport security authorities. Our other purchases, especially books, developed into a problem in view of the 20-kilogram baggage allowance. Geoff revealed himself to be a packing genius.

And so, we survived our first two trips, during which we had looked for socialism and found China. Actually, we became more and more convinced with every trip that the more we saw of China, the less we knew about the place. This society was an enigma. What now was certain knowledge changed only a little later into its opposite. What we did grasp was the size and the diversity of the country, its development and its belief in a "glorious future". Our questions became more and more numerous. But the answers we received rarely made us any the wiser. And yet back then we felt ourselves to be witnessing events of historic importance. We were in China, others were not. And what do you do in such a case? You disseminate the knowledge you have acquired, and so Geoff and I went on tour, from Tecklenburg in the North to Oberstdorf (Allgäu) in the South. We were a good team, Geoff. People listened to us.

You probably won't be surprised to learn that I didn't have to persuade Geoff to go on yet another trip. This time the journey was to take place in the summer. It would take us to cities like Wuhan, known as "Hot Furnaces", and through the Three Gorges of the Yangtze. This trip turned out to be a real photo orgy. But it was not without its dangers, for instance when the inhabitants set up their beds on the unlit streets because it was so hot. Occasionally Geoff had his work cut out to avoid driving into somebody's bed. Once we were home again, Geoff started delving more deeply into the history of the Yangtze and those who lived on its banks. Geoff became an expert on sampans and junks. And then we decided to write about it all. When we started writing I discovered a new side of Geoff, his - shall we say - literary side. And I as a mere German had the interesting experience of being taught my own language by an Englishman. Up to that point I had 
never heard of the German word "treideln", which refers to the practice of a boat being towed along a river or canal by animals or human beings using a towpath alongside the waterway. I must say it was all a lot of fun. "Changjiang - the Long River" was published in England and Hong Kong. Thanks, Geoff, for having me as your co-author. Joint seminars in Aachen and further publications followed. A lovely time and a friendship I'll never forget.

The 1980 trip was something special: apart from China our itinerary also took in Hong Kong, Thailand and Singapore as well as Sri Lanka. In other words, the return journey consisted of a number of stages. I hardly need mention that we had to have a gin and tonic in the Raffles Hotel, Singapore. For medical reasons, of course - it's simply the best way to ward off malaria. Cockroaches in the salad in our Bangkok hotel - ok, you can get used to that. But in Sri Lanka things got really stressful.

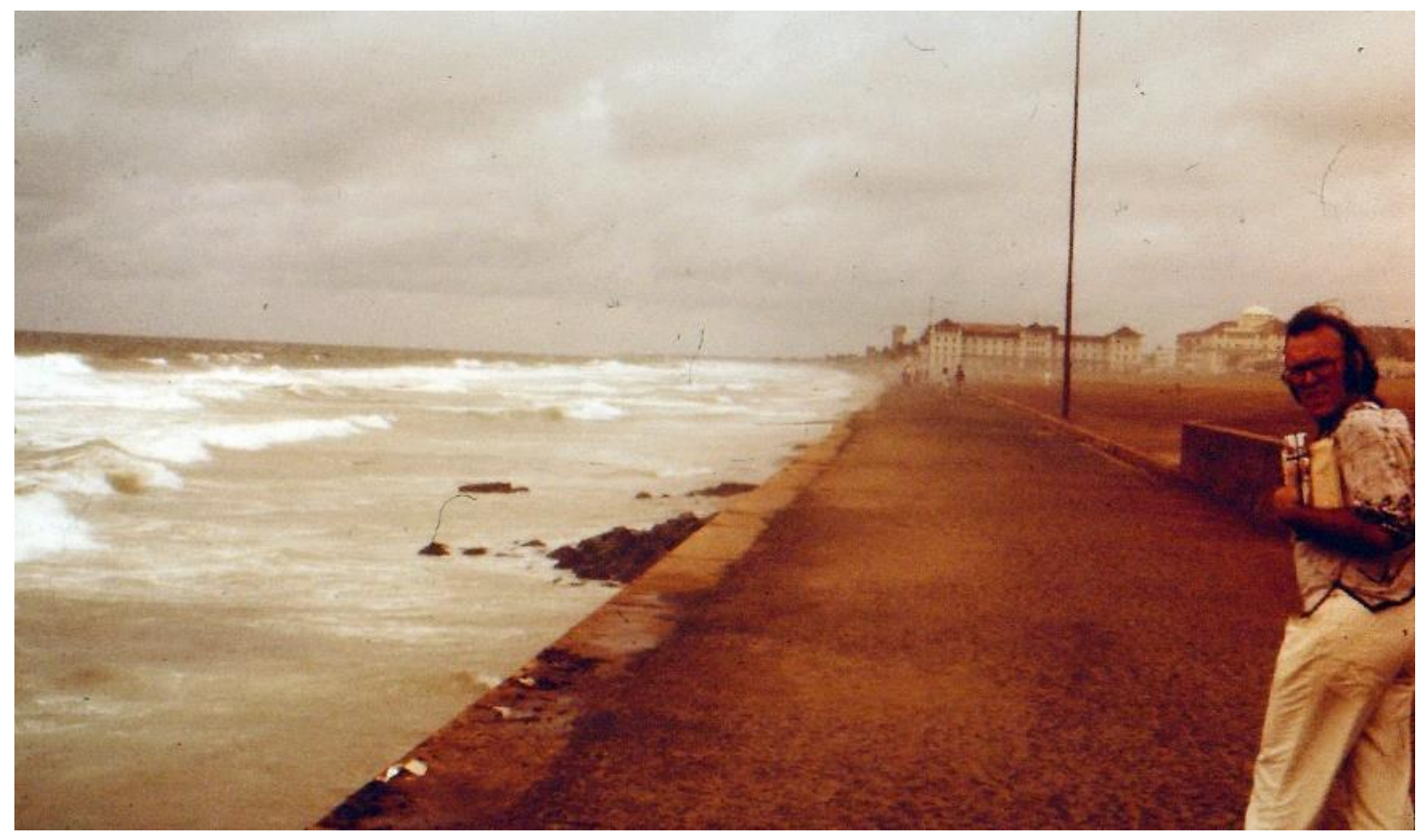

In Colombo I knew some people of the Goethe Institute whose guest house we were able to stay in. During the night, Geoff woke with a start - what was that?! Snakes? They had already crossed our path in Singapore - right in the city centre. We preferred them when they were in a Chinese saucepan. Anyway, we set off to find out what was causing the noise. Our enquiring minds were leaving us no peace - and then we discovered the source of the problem: the uncanny noises were emanating from the bathroom. We opened the door and switched on the light. And then we saw a whole armada of giant cockroaches. What were we to do? Geoff had the solution. He started sealing the bathroom door with newspaper. A good night's sleep was now guaranteed.

Foodwise, Sri Lanka was quite a comedown for me. Geoff was ecstatic. A curry - and then another curry - and then yet another curry. That must simply be a legacy of the British Empire: Indian curries, all well and good - but not several times a day, if you don't mind. We went to Kandy for a few days to visit some relatives of our hosts'. A bungalow in the jungle - a new challenge. Everything was open to the elements. "Please 
don't forget to search the room for snakes!" There are a few photos of us chatting on the veranda over a cup of tea or a gin and tonic - and when I look at those pictures I always have to think the British must have felt just as relaxed in their South-Asian Empire as those people look.

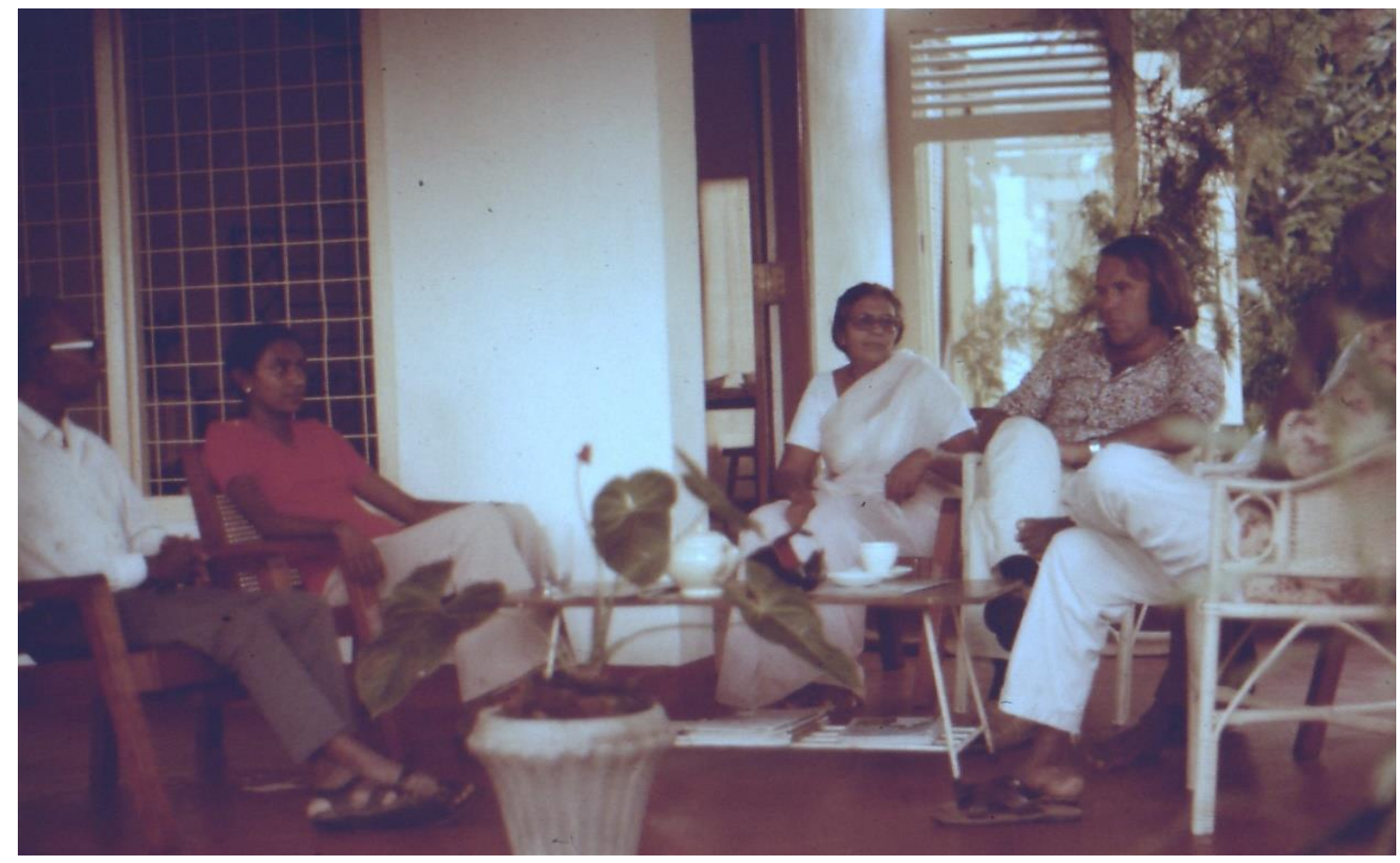

We watched the Perahera and were thrilled by it. We were travelling in an old VW Beetle through jungles and bamboo forests and across rivers. And then back to the beach in Colombo.

Whilst Geoff over the years focused his attention time and again on India and frequently visited the country, he unfortunately didn't succeed in persuading me to go with him. India also remained alien territory to me even though I had published a few things there - about China of course. But although our travels again and again took us in different directions, there was nothing nicer than to meet up over lunch and chat about them. We did once go back to China again, this time together with our wives. For Geoff, China in 2005 was a very different China. Having returned there frequently in the interim, I was familiar with the way the place had developed. But Geoff was really shocked by the way some things had changed. The place had become Western, capitalistic. Cars had begun to replace the bicycles. People were wearing brightly coloured clothes. Women were wearing skirts again. The morbid charm of socialism was somehow missing. And so, during this trip we found ourselves embarking on a journey of rediscovery. "Now which hotel did we stay in? Do you remember?" Geoff was well prepared. He had always kept a diary but often the old things simply weren't there anymore. Or was it just our memories that were beginning to fade? Some cities had fundamentally changed. But Suzhou still had the charm of yesteryear: the canals, the Venice of the East. In Peking the portrait of 
Mao was still hanging over the Gate of Heavenly Peace. And yet - the time really was over, as we had already been told by one of the locals some years earlier.

Geoff found the Terra Cotta Army enthralling, and so did our wives. But I couldn't help thinking repeatedly: "It all used to be so much nicer - there weren't so many tourists". But what were we now but tourists ourselves? That was evident not only in the fact that we were unaccompanied by guides or interpreters but also in the way Geoff was taking out his Lonely Planet and reading it out to us at every possible opportunity. I can still hear my own repeated question: "So what does the Lonely Planet say about it?"

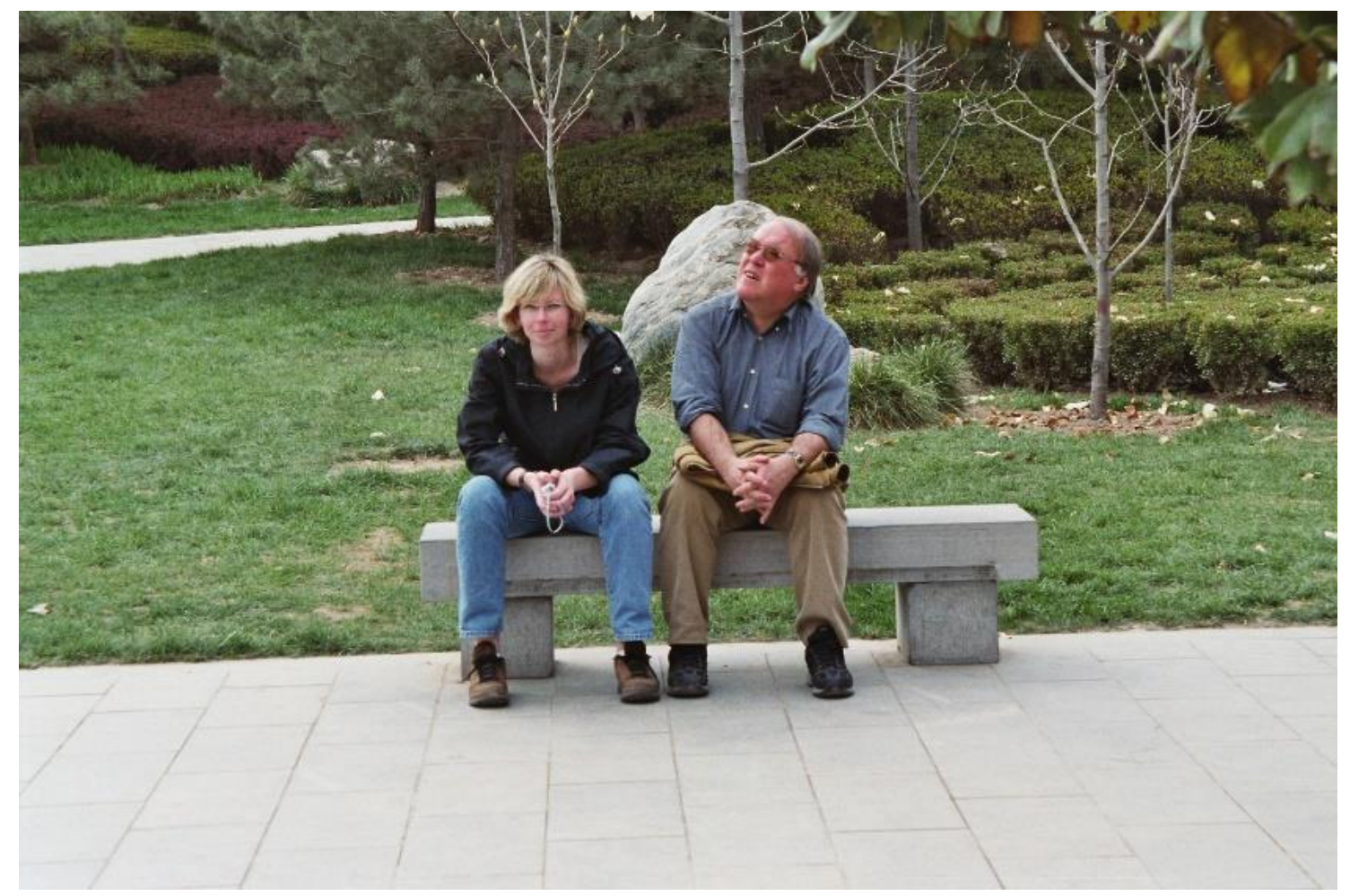

What a pity that that was our last trip together. For me, travel and Geoff will always go hand in hand. Curiosity, an eagerness to discover new things and to rediscover familiar older things. I'm going to miss all that. Just as I'm also going to miss those many lunchtime conversations about the University, about Trump, about Brexit and about all the plans we still had...And I am also missing no longer being able to ask him: "Remember when we...?" When a friend dies, it's not only a person that goes but also that person's memories which have become part of our own lives.

Over forty years with you, Geoffrey! What times we had, what trips we took, what conversations we had. How I'm going to miss it all...

Bionote: Dr. Manfred F. Romich, M.A., is a sociologist and political scientist with a focus on environmental and China studies. He worked as researcher and lecturer at the 
Coolabah, $\mathrm{Nr}$ 28, 2020, ISSN 1988-5946, Observatori: Centre d'Estudis Australians $i$

Transnacionals / Observatory: Australian and Transnational Studies Centre,

Universitat de Barcelona

Institute of Sociology at RWTH Aachen University and retired in 2017. He now works as a consultant to academic institutions in the EU.

He was guest professor at the Shandong Jianzhu University in Jinan/China for four years, held positions as a research fellow with a member of the Federal Parliament of Germany in the early 1990s and as an external EU-Expert to the Ministry of Labor of Romania in the early 2000 s.

Since 1978 he used to visit China and Southeast Asia frequently and committed common research projects with Chinese institutes on environmental issues. His works were published in 14 countries including Singapore, Vietnam, China, Hongkong, and India. He also worked as a freelance journalist for journals in Germany and Italy and was an external fellow at the Research Institute for Peace Policy in Starnberg and the Research Centre in Jülich (Germany). He most recently published about marriage, family, and the demographic problems in China (2019). 